\title{
Host Characteristics Do Not Affect Community Structure of Ectoparasites on the Fishing Bat Noctilio leporinus (L., 1758) (Mammalia: Chiroptera)
}

\author{
Mauricio O Moura/ ${ }^{+}$, Marcelo O Bordignon*, Gustavo Graciolli**
}

\begin{abstract}
Núcleo de Pesquisas Ambientais, Departamento de Ciências Biológicas, Universidade Estadual do Centro-Oeste, Caixa Postal 3010, 85010-090 Guarapuava, PR, Brasil *Departamento de Ciências do Ambiente, Centro Universitário de Corumbá, Corumbá, MS, Brasil **Departamento de Zoologia, Universidade Federal do Paraná, Curitiba, PR, Brasil
\end{abstract}

Patterns of parasite abundance and prevalence are thought to be influenced by several host characteristics such as size, sex, developmental stage, and seasonality. We examined two obligatory ectoparasites of the bat Noctilio leporinus (L.) (Chiroptera, Noctilionidae) to test whether prevalence and abundance of Noctiliostrebla aitkeni Wenzel and Paradyschiria fusca Speiser (Diptera, Streblidae) are influenced by the host characteristics. During this survey, 2110 flies were collected. The total abundance was $1150 \mathrm{~N}$. aitkeni and $950 \mathrm{P}$. fusca. The prevalence of both species was shown to be superior to $75 \%$ and neither host size, sex, reproductive stage nor season influenced significantly the variation of the observed values. N. aitkeni were more abundant than $\mathrm{P}$. fusca in all seasons except winter. Both flies showed a significant seasonal variation in terms of abundance but host biological characteristics (host size, sex, and reproductive stage) did not play a significant role as structuring factors of the batflies component community.

Key words: parasitological index - batfly - component community - Noctilionidae - Streblidae

Ectoparasites and their hosts constitute a well suitable system for studying questions concerning diversity and abundance patterns since in this kind of interaction spatial and temporal scales are intrinsic factors (Janovy et al. 1992). In this sense, insects are ubiquitous as ectoparasites and use as hosts mainly mammals of the orders Rodentia and Chiroptera, and birds (Marshall 1981, Clayton $\&$ Moore 1997). The great majority of papers about insect ectoparasites ecology have concentrated on rodent and bird ectoparasites and relatively few papers deal with bat ectoparasites (Marshall 1971, Kunz 1976, Fritz 1983, Linhares \& Komeno 2000). This is remarkable since bats are one of the most diverse mammals of the Neotropics and harbor several ectoparasites ranging from specifics to generalists (Wenzel \& Tipton 1966).

The system formed by the "fishingbat" Noctilio leporinus L. and its ectoparasites seems to be very good to study and test predictions about population and community patterns. The fishbat $N$. leporinus is a large (50-90 g) piscivore species common in the Neotropics, with colonies found in hollow trees and caves (Hood \& Jones 1984). This is a polygamous species that roost in discrete groups of multiple females and one or two males,

Financial support: Conselho Nacional de Pesquisa, CNPq, and The State of Paraná Research Foundation, Fundação Araucária. Contribution number 1434 of Dept. of Zoology, Universidade Federal do Paraná.

Corresponding author. Fax + 55-42-623.8644. E-mail: moura@unicentro.br

Received 15 April 2003

Accept 10 July 2003 with females groups remaining together for a long period (Brooke 1997).

The ectoparasites found in this species are comprised of mites (Acari), bedbugs (Hemiptera), batflies (Diptera, Streblidae) and fleas (Siphonaptera, Ischnopsyllidae) (Guerrero 1996, 1998, Graciolli et al. 2000, Linardi \& Guimarães 2000). Regarding batflies, there are three genera that are specific of the Noctilio spp.: Xenotrichobius Wenzel, 1966; Noctiliostrebla Wenzel, 1966; and Paradyschiria Speiser, 1900 (Guerrero 1998). This specificity indicates a highly historical component linking these batflies to the Noctilio genus. Although, the occurrence of these ectoparasites in Noctilio is historical, their fluctuations and interactions are under the control of ecological factors acting on a local spatial and temporal scale.

In this paper, we will describe the batfly community of the $N$. leporinus. More specifically, we will describe the temporal patterns of prevalence and abundance as well as identify the possible causal relationships among host sex, size, and developmental stage on batflies prevalence and abundance.

\section{MATERIALS AND METHODS}

Bats were sampled monthly from January 1998 to February 1999 at Guaratuba Bay, Southern Brazil (2550'S; $\left.48^{\circ} 34^{\prime} \mathrm{W}\right)$. Each sampling consisted of a four-night trap program between 18:00 p.m. and 6:00 a.m. All samplings were done using three mist nets of $2.6 \times 9 \mathrm{~m}$ set out above seawater and perpendicularly to the coast. After capture, the bats were removed to the laboratory, anesthetized with ether and then handled. Selected biological measures (weight, forearm length, and reproductive status) were taken and collection procedures made, the bats were marked and then released in the vicinities of the collection 
site. The ectoparasites were collected with fine forceps and placed in glass vials containing $70 \%$ ethanol. Subsequently, each sample was analyzed and all specimens identified, sorted by sex and counted. Voucher collection (100 specimens) was deposited at Coleção de Entomologia Pe Jesus Santiago Moure, Departamento de Zoologia (DZUP), Universidade Federal do Paraná, Brazil.

Prevalence and abundance were calculated following the propositions set forth by Bush et al. (1997). Abundance data were skewed, so the dataset was transformed using $\log (\mathrm{x}+1)$ prior to statistical analysis. The range in bat size, measured by forearm length, was divided in four size classes (mm): (1) 92-93, (2) 94-95, (3) 96-97, and (4) 98-99. The reproductive stages were recorded as follows: non-reproductive males, non-reproductive females, lactating females and scrotal testes male.

Regarding abundance, differences between parasites were addressed using a $t$ test or an analogous nonparametric test. We tested the null hypothesis of independence of effects of season, host sex, size and developmental stage on prevalence by means of a chisquare contingence table (Zar 1984). The effects of season, host sex, size, and developmental stage on abundance were addressed using Analysis of Variance. This was done using a general linear model option and the null hypothesis of neither effects nor interactions were rejected if $\mathrm{P}<0.05$. To test the relatedness of sex and weight an analysis of covariance (ANCOVA) was done using weight as a covariate. All the analyses were performed in STATISTICA (StatSoft Inc. 1996).

\section{RESULTS}

We collected four ectoparasites species from the 56 (n) N. leporinus L. captured. Two of then were streblids, P. fusca Speiser and N. aitkeni Wenzel, one was a heteropteran cimicidae Latrocimex spectrans Lent and one was an undescribed Acari. The analyses were carried out on two of the batflies species only because the Acari and L. spectrans did not have enough specimens to undertake a statistical analysis.

During the field trap program, we did not collect bats in the Spring even though our field efforts were the same as in the other seasons. Personal observation during a subsequent year proved that this is due to a local behavioral pattern that spread out the home range of this population (MO Bordignon unpubl. manusc.). The catchability and size of the bats, recorded as right forearm length, did not differ significantly between seasons (catchability $\mathrm{F}_{3,17}=1,01, \mathrm{P}=0,40$; forearm length $\mathrm{F}_{3,52}=$ $1,04, \mathrm{P}=0,31)$, but there was a significant difference in weight $\left(\mathrm{F}_{3,52}=8.06, \mathrm{P}<0,001\right)$ within seasons too.

Generally, $N$. aitkeni were more abundant on bats $(11,71$ $\pm 10,49)$ than P. fusca $(7,71 \pm 7,98)$ (Kolmogorof-Smirnov test $-\mathrm{P}<0,001)$. The abundance of $N$. aitkeni ranged from 0 to 48 flies per bat whereas $P$. fusca ranged from 0 to 39 flies per bat. Considering seasonal patterns, this trend was reversed only in the winter and in favor of $P$. fusca (Table). The number of males and females collected within each species did not show a significant trend, the differences being attributed to random variation (P. fusca $\mathrm{t}_{1,110}=1,64 \mathrm{P}=0,10$, and $N$. aitkeni $\left.\mathrm{t}_{1,110}=1,02, \mathrm{P}=0,30\right)$.

Prevalence was in general higher than $75 \%$ for $N$. aitkenii and $90 \%$ for $P$. fusca (Table). Prevalence values (Fig. 1) for both species was shown to be independent between seasons $\left(\chi^{2}, 3 \mathrm{df}, \mathrm{P}>0,14\right.$ for $N$. aitkeni and $\mathrm{P}>$ 0,88 for $P$. fusca) though $N$. aitkeni values decreased toward winter whilst $P$. fusca showed no trend. The sex of the host did not influence prevalence of both species $\left(\chi^{2}\right.$, $1 \mathrm{df}, \mathrm{P}>0,7$ for $N$. aitkeni and $\mathrm{P}>0,5$ for $P$. fusca) but males were slightly more parasitized than females (Fig. 1). Following the same pattern, host size $\left(\chi^{2}, 4 \mathrm{df}, \mathrm{P}>0,31\right.$ for $N$. aitkeni and $\mathrm{P}>0,79$ for $P$. fusca) and host reproductive stage $\left(\chi^{2}, 1 \mathrm{df}, \mathrm{P}>0,23\right.$ for $N$. aitkeni and $\mathrm{P}>0,61$ for $P$. fusca) were not a source of variation for prevalence in both batflies (Fig. 1). Although we did not find a significant trend between prevalence and host size; $N$. aitkeni parasitized more on larger and intermediary bats than small-sized bats.

Seasonal variation on batflies abundance was observed and shown opposite tendencies. $N$. aitkeni showed a declining abundance toward winter (Fig. 2) and P. fusca were more abundant in winter than any other season (Fig. 2). In both cases, there was a significant effect of season on abundance (P. fusca $\mathrm{F}_{3,52}=2,85 \mathrm{P}=0,046$ and $N$. aitkeni $\left.\mathrm{F}_{3,52}=4,97, \mathrm{P}=0,004\right)$. As we found for the whole dataset, the abundance of males and females ectoparasites did not fluctuate more between seasons than expected by chance (interaction term parasites sex and season; P. fusca $\mathrm{F}_{3,104}=0,41 \mathrm{P}=0,74$ and $N$. aitkeni $\left.\mathrm{F}_{3,104}=0,76, \mathrm{P}=0,97\right)$.

TABLE

Prevalence (percentage of bats in sample that harbor ectoparasites) and abundance (number of ectoparasites found in bats; mean \pm SD) of Paradyschiria fusca Speiser and Noctiliostrebla aitkeni Wenzel by season, collected on Noctilio leporinus L. from January 1998 to February 1999 at Guaratuba Bay, Southern Brazil

\begin{tabular}{|c|c|c|c|c|c|}
\hline \multirow[b]{2}{*}{ Season } & \multirow[b]{2}{*}{ Sample size } & \multicolumn{2}{|c|}{ Prevalence } & \multicolumn{2}{|c|}{ Abundance } \\
\hline & & P. fusca & N. aitkeni & P. fusca & N. aitkeni \\
\hline Summer - 1998 & 14 & 100 & 100 & $6,40 \pm 6,59$ & $12,85 \pm 13,13$ \\
\hline Autumn & 23 & 91 & 82,6 & $6,10 \pm 6,32$ & $3,25 \pm 3,40$ \\
\hline Winter & 4 & 100 & 75 & $21,75 \pm 16,15$ & $17,93 \pm 10,4$ \\
\hline Spring $^{a}$ & & & No samples taken & & \\
\hline Summer - 1999 & 15 & 93 & 100 & $7,60 \pm 5,38$ & $17,93 \pm 10,4$ \\
\hline
\end{tabular}

$a$ : for full explanation of spring patterns see Results. 

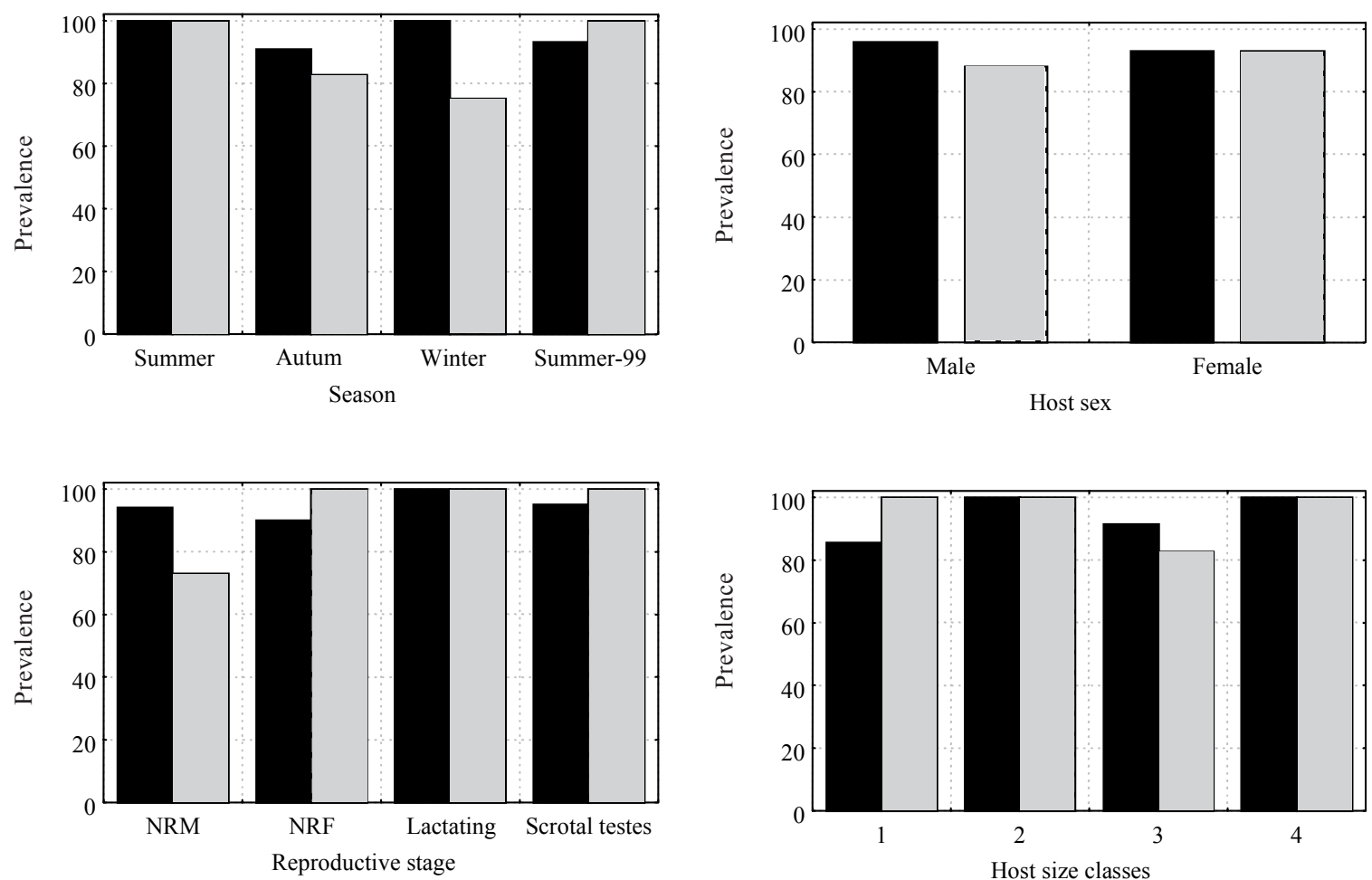

Fig. 1: variation of prevalence of Noctiliostrebla aitkeni (black bars), and Paradyschyria fusca (grey bars) according to seasons, host sex, size and reproductive stage. Reproductive stages are as follow: non-reproductive males (NRM), non-reproductive females (NRF), lactating females (Lactating), and scrotal testes male (Scrotal testes). Host size (forearm length in mm) classes are: (1) 92-93, (2) 94-95, (3) 9697, and (4) 98-99.
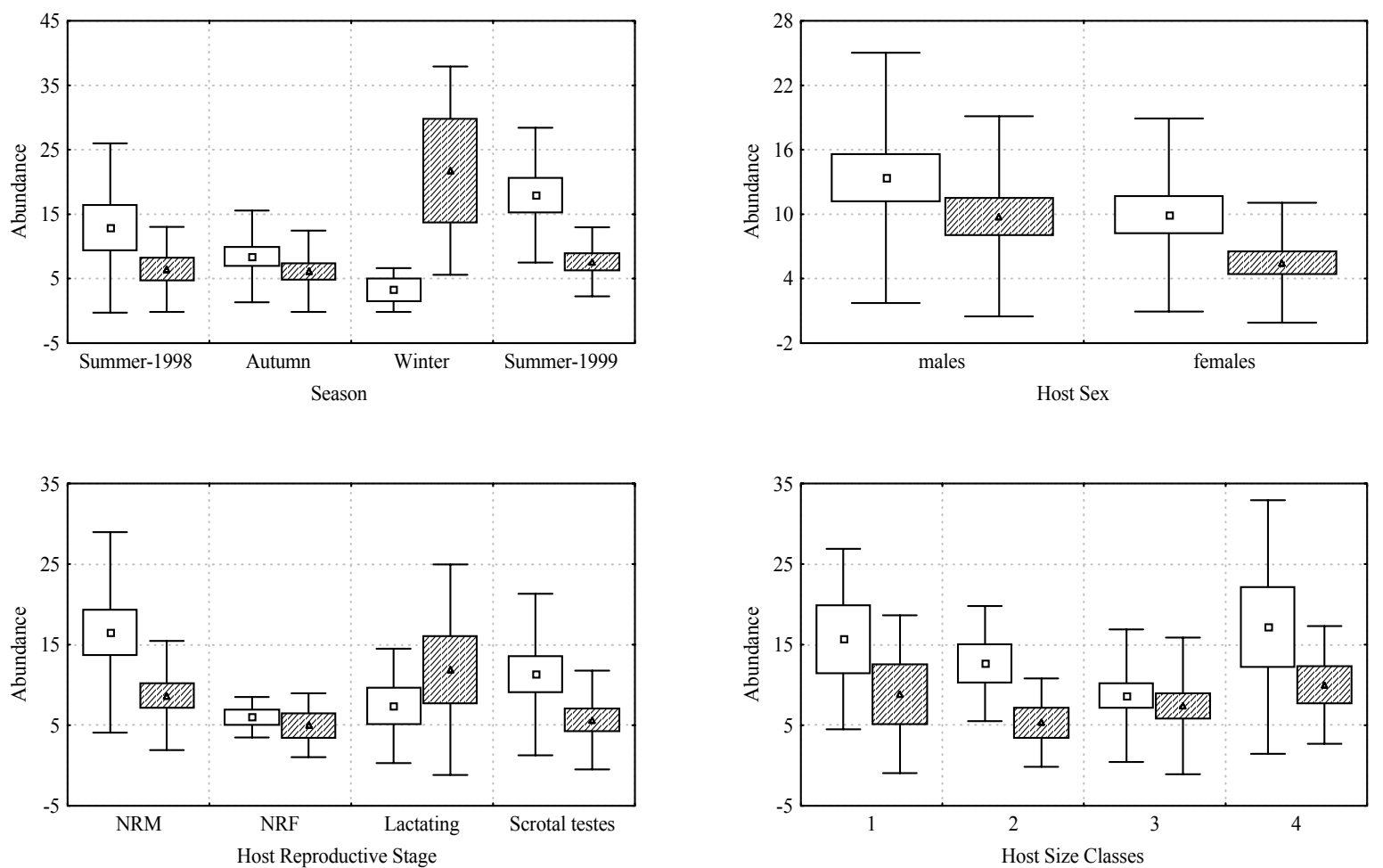

Fig. 2: abundance patterns of Noctiliostrebla aitkeni (open box) and Paradyschyria fusca (shaded box) according to seasons, host sex, reproductive stage, and size. Values represent means, standard errors, and standard devious. Reproductive stages are as follow: nonreproductive males (NRM), non-reproductive females (NRF), lactating females (Lactating), and scrotal testes male (Scrotal testes). Host size (forearm length in mm) classes are: (1) 92-93, (2) 94-95, (3) 96-97, and (4) 98-99. 
Abundance of both batflies was higher on male than female hosts (Fig. 2). The results of the analysis of covariance demonstrated that weight ( $P$. fusca $\mathrm{F}_{3,53}=2,27$ $\mathrm{P}=0,28$ and $N$. aitkeni $\left.\mathrm{F}_{3,53}=2,14, \mathrm{P}=0,14\right)$ and sex of the host (P. fusca $\mathrm{F}_{1,53}=1,29, \mathrm{P}=0.25$ and $N$. aitkeni $\left.\mathrm{F}_{1,53}=1,92, \mathrm{P}=0,17\right)$ were not a source of variation for batflies abundance. Even though these analyses were not significant, a plot of abundance against weight led to a negative slope for $N$. aitkeni and a positive slope for $P$. fusca, which indicated that the direction of variation was reversed between these two batflies.

Variation of abundance between host size classes (Fig. 2) appear to be a chance event, considering host size as the main effect (P. fusca $\mathrm{F}_{3,52}=1,28, \mathrm{P}=0,28$ and $N$. aitkeni $\mathrm{F}_{3,52}=2,59, \mathrm{P}=0,06$ ) or an interaction term between parasite sex and host size classes ( P. fusca $\mathrm{F}_{4.102}=0,32 \mathrm{P}$ $=0,86$ and $N$. aitkeni $\left.\mathrm{F}_{4,102}=0,07, \mathrm{P}=0,98\right)$. Both species showed the same pattern in which abundance was high in bats belonging to classes 1 (between 92 and $93 \mathrm{~mm}$ ) and 4 (between 98 and $99 \mathrm{~mm}$ ), the two tails of bat size distribution.

The host's reproductive stage did not significantly affect the variations of batflies abundance $\left(P\right.$. fusca $\mathrm{F}_{352}$ $=1.10, \mathrm{P}=0,35$ and $N$. aitkeni $\left.\mathrm{F}_{3,52}=2,26, \mathrm{P}=0,09\right)$. Likewise, we did not find the host's reproductive stage to affect significantly the abundance of males and females batflies, either ( $P$. fusca $\mathrm{F}_{3,104}=0.05, \mathrm{P}=0,98$ and $N$. aitkeni $\left.\mathrm{F}_{3,104}=0,01, \mathrm{P}=0,99\right)$. Despite absence of effects of host reproductive status on batflies, $N$. aitkeni were more abundant on non-reproductive male bats than any other reproductive classes whilst $P$. fusca were more abundant on lactating female bats (Fig. 2).

\section{DISCUSSION}

According Marshall (1981) besides interactions between species, several of the host's characteristics such as sex, reproductive stage and size are hypothesized to influence the distribution and abundance of ectoparasites. Nevertheless, the component community data of $N$. leporinus failed to find any systematic trend between the above cited factors and batflies abundance. Considering the factors examined, just season showed a significant effect upon batflies abundance.

The absence of a systematic trend relating probable controlling factors and population abundance in this system could be an evidence of a very stabilized relationship. During the study we were not able to find any tissue reaction provoked by batflies. This finding, linked with absence of preference for reproductive stage, size and sex points to be an evidence of a lack of apparent negative effects on the host. Such relationships between parasites and hosts could come from several different sources.

Theoretical predictions stated that natural selection favors high rates of parasite transmission and reproduction (Bull 1994). Batflies are transmitted through direct contact or close proximity between bats at roost (Marshall 1981). As batflies depended on host fitness to reproduce and spread, then natural selection should have pointed toward lower levels of virulence, even in the case of a horizontal transmission. This in turn will select for lesser effects on host fitness, opening the possibility to stability in the host-parasite system. Theoretical models of virulence evolution predict a similar scenario, either through maximizing growth rates within hosts (May \& Novak 1994) or to increasing prevalence due to higher contact rates (Lipsitich et al. 1996). Although theoretical models could shed light on the pattern, we have no data on the extension of host's response to batflies for comparisons. In this case, experimental manipulation is needed to understand the fitness relationship between batflies and their host.

Another pattern emerging from the data suggests that hosts were not a limiting factor since prevalence and abundance did not change with the host's characteristics. The behavioral characteristics of the bat together with the host availability in the area could be responsible for such a pattern. According to Brooke (1997) N. leporinus roost in discrete groups (composed by 1-11 individuals) in hollow trees and caves, with colonies ranging in size from a few to a hundred bats (Hood \& Jones 1984). This kind of spatial arrangement inside roosting areas plus movements between bat clusters should enhance host finding. In addition, with roost characteristics, the behavior of bats includes seasonal movements between different bat groups (Brooke 1997), which should facilitate the colonization of new sites.

Seasonal patterns in parasites could be a by-product of the hosts' seasonal fluctuations. The seasonal patterns described here were not a product of seasonal differences in catchability of $N$. leporinus, but for $P$. fusca, it could be a sampling artifact since seasonal differences in abundance were marginally significant and highly related to winter samples. One striking feature of the populational fluctuations described here was the similarity of abundance values taken from summer samples of different years, which could also be an evidence of a highly stabilized population dynamics. In addition, Brook (1997) describes that bat clusters remain together for several years, reforcing this line of reasoning.

The prevalence of batflies parasitizing $N$. leporinus is one of the highest reported for ectoparasites, with more than $75 \%$ of individuals parasitized. Similar prevalence was obtained by Guerrero (1996) on component community of $N$. albiventris where $92.9 \%$ of bats were parasitized by Noctiliostrebla maai Wenzel and $98.2 \%$ by Paradyschiria parvula Wenzel. However, mean abundance was less than found in this paper.

In addition, parasitological indices obtained in the present study were higher than those of the Noctilio system observed by Guerrero (1996) and Komeno and Linhares (1999). The preference for host characteristics seems to be quite variable (Kunz 1976, Marshall 1981, 1982, Guerrero 1996, Komeno \& Linhares 1999) and probably dependent upon host sample size, what makes broader generalizations difficult. Likewise, abundance was very pronounced, but with $N$. aitkeni being more abundant than P. fusca. This pattern was different from those reported by Wenzel and Tipton (1966) and Guerrero (1996) where Paradyschiria were the most abundant. These authors dealt with data gathered respectively at Central and Southwest America and our data are derived from 
Southeast Brazil, it could be supposed the occurrence of a geographical variation on community hierarchy from North to South.

In conclusion, several host characteristics are thought to play significant roles on the population structure of batflies. Our data failed to support the hypothesis based on host size, sex and developmental and population structure. It is necessary to search for another hypothesis regarding population regulation such as bat grooming (Overal 1980), predators and parasites (Ross 1961, Overal $1980)$ as well as the temporal and spatial effects of these factors on the ectoparasites population biology.

\section{ACKNOWLEDGMENTS}

To Flávio Popazoglo for critical reading. To two anonymous referees for comments and suggestions.

\section{REFERENCES}

Brooke AP 1997. Social organization and foraging behaviour of the fishing bat Noctilio leporinus (Chiroptera: Noctilionidae). Ethology 103: 421-436.

Bull JJ 1994. Virulence. Evolution 48: 1423-1437.

Bush AO, Lafferty KD, Lotz JM, Shostaki AW 1997. Parasitology meets ecology on its own terms: Margolis et al. Revisisted. J Parasitol 83: 575-583.

Clayton DH, Moore J 1997. Host-Parasite Evolution. General Principles and Avian Models, Oxford University Press, Oxford.

Fritz GN 1983. Biology end ecology of bat flies (Diptera: Streblidae) on bats in the genus Carollia. J Med Entomol 20: $1-10$.

Graciolli G, Bordignon MO, Moura MO 2000. Ocorrência de Latrocimex spectans Lent (Hemiptera, Cimicidae, Latrocimicinae) no Paraná, Brasil. Revta Bras Zool 16: 913.

Guerrero R 1996. Streblidae (Diptera: Pupipara) parásitos de los murciélagos de Pakitza, Parque Nacional Manu (Perú). In DE Wilson, A Sandoval (eds), MANU: La Biodiversidad del Sureste del Perú, Smithsonian Institution, Washington, DC, p. 627-641.

Guerrero R 1998. Notes on Neotropical batflies (Diptera, Streblidae). II. Review of the genus Xenotrichobius. Acta Parasitol 43: 142-147.
Hood CS, Jones Jr JK 1984. Noctilio leporinus. Mammalian Species 216: 1-7.

Janovy J, Clopton RE, Percival TJ 1992. The roles of ecological and evolutionary influences in providing structure to parasite species assemblages. J Parasitol 78: 630-640.

Komeno CA, Linhares AX 1999. Batflies parasitic on some phyllostomid bats in Southeastern Brazil: parasitism rates and host-parasite relationships. Mem Inst Oswaldo Cruz 94: 151-156.

Kunz TH 1976. Observations on the winter ecology of the bat fly Trichobius corynorhini Cockerell (Diptera: Streblidae). $J$ Med Ent 12: 631-636.

Linardi PM, Guimarães LR 2000. Sifonápteros do Brasil, Museu de Zoologia USP/FAPESP, São Paulo.

Linhares AX, Komeno CA 2000. Trichobius joblingi, Aspidoptera falcata, and Megistopoda proxima (Diptera: Streblidae) parasitic on Carollia perspicillata and Sturnira lilium (Chiroptera: Phyllostomidae) in Southeastern Brazil: sex ratios, seasonality, host site preference, and effect of parasitism on the host. J Parasitol 86: 167-170.

Lipsitch M, Siller S, Novak MA 1996. The evolution of virulence in pathogens with vertical and horizontal transmission. Evolution 50: 1729-1741.

Marshall AG 1971. The ecology of Basilia hispida (Diptera: Nycteribiidae) in Malaysia. J Anim Ecol 40: 141-154.

Marshall AG 1981. The Ecology of Ectoparasitic Insects, Academic Press, London.

Marshall AG 1982. Ecology of insects ectoparasitic on bats. In TH Kunz, Ecology of Bats, Plenum Press, New York, p. 369-401.

May RM, Novak MA 1994. Superinfection, metapopulation dynamics and the evolution of diversity. $J$ Theor Biol 170: 95-114.

Overal WL 1980. Host-relations of the batfly Megistopoda aranea (Diptera: Streblidae) in Panamá. University Kansas Sci Bul 52: 1-20.

Ross A 1961. Biological studies on bat ectoparasites of the genus Trichobius (Diptera: Streblidae) in North America, North of Mexico. Wasmann J Biol 19: 229-246.

StatSoft, Inc. 1996. STATISTICA for Windows [Computer program manual], Tulsa, US.

Wenzel RL, Tipton VJ 1996. Ectoparasites of Panama, Field Mus Nat Hist, Chicago.

Zar JH 1984. Biostatistical Analysis, 2nd ed., Prentice-Hall, US. 